\title{
Dithiadiazuliporphyrin: Facile Generation of Carbaporphyrinoid Cation Radical and Dication
}

Natasza Sprutta, Marta Świderska and Lechosław Latos-Grażyński*

Department of Chemistry, University of Wrocław, 14 F. Joliot-Curie St., Wrocław 50 383, POLAND

SUPPLEMANTARY INFORMATION

\begin{tabular}{|c|c|c|}
\hline Compound & 1 & 2 \\
\hline crystals grown by & $\begin{array}{l}\text { slow diffusion of } \mathrm{MeOH} \text { into } \mathrm{CH}_{2} \mathrm{Cl}_{2} \\
\text { solution }\end{array}$ & $\begin{array}{l}\text { slow diffusion of toluene into } \mathrm{CH}_{2} \mathrm{Cl}_{2} \\
\text { solution }\end{array}$ \\
\hline crystal habit & navy blue plates & dark red plates \\
\hline formula & $\mathrm{C}_{60} \mathrm{H}_{48} \mathrm{~S}_{2}$ & $\mathrm{C}_{60} \mathrm{H}_{44} \mathrm{~S}_{2} \cdot \mathrm{CH}_{2} \mathrm{Cl}_{2}$ \\
\hline fw & 832.3192 & 914.0917 \\
\hline$a, \AA$ & $26.021(2)$ & $13.702(4)$ \\
\hline$b, \AA$ & $9.9860(10)$ & $14.778(4)$ \\
\hline$c, \AA$ & $16.950(2)$ & $14.861(4)$ \\
\hline$\alpha,^{\circ}$ & 90.00 & $118.82(3)$ \\
\hline$\beta,^{\circ}$ & $99.940(10)$ & $92.55(3)$ \\
\hline$\gamma,^{\circ}$ & 90.00 & $114.21(3)$ \\
\hline$V, \AA^{3}$ & $4338.3(7)$ & 2291.5(17) \\
\hline$Z$ & 4 & 2 \\
\hline$D_{\text {calc }}, \mathrm{g} \cdot \mathrm{cm}^{-3}$ & 1.276 & 1.325 \\
\hline crystal system & monoclinic & triclinic \\
\hline space group & $C 2 / c$ & $P-1$ \\
\hline crystal size, $\mathrm{mm}$ & $0.4 \times 0.3 \times 0.15$ & $0.5 \times 0.21 \times 0.16$ \\
\hline$\mu, \mathrm{mm}^{-1}$ & 0.164 & 0.275 \\
\hline absorption correction & not applied & not applied \\
\hline $\mathrm{T}_{\min }, \mathrm{T}_{\max }$ & $0.9371,0.9757$ & $0.8748,0.9573$ \\
\hline$T, \mathrm{~K}$ & $100(2)$ & $100(2)$ \\
\hline$\theta$ range & $23.14 \leq \theta \leq 36.63$ & $2.98 \leq \theta \leq 25.00$ \\
\hline \multirow[t]{3}{*}{$h k l$ range } & $-43 \leq h \leq 34$ & $-15 \leq h \leq 16$ \\
\hline & $-16 \leq k \leq 12$ & $-17 \leq k \leq 17$ \\
\hline & $-27 \leq l \leq 22$ & $-17 \leq l \leq 16$ \\
\hline \multicolumn{3}{|l|}{ reflections: } \\
\hline mesured & 8179 & 7614 \\
\hline unique, $I \geq 2 \sigma(I)$ & 5135 & 5416 \\
\hline parameters/restraints & $352 / 0$ & $687 / 0$ \\
\hline$R 1$ & 0.0598 & 0.0621 \\
\hline$w R 2$ & 0.1606 & 0.1477 \\
\hline $\mathrm{S}$ & 1.093 & 1.116 \\
\hline
\end{tabular}

Table 1

\section{Experimental}

$5,10,15,20$-tetra-p-tolyl-22,24-dithiadiazuliporphyrinonogen (1): 2,5-Bis[( $p$-tolyl)hydroxymethyl] thiophene $(0.2 \mathrm{mmol}, 56.9 \mathrm{mg})$ and azulene $(0.2 \mathrm{mmol}, 22.5 \mathrm{mg})$ were added to dry $\mathrm{CH}_{2} \mathrm{Cl}_{2}(250 \mathrm{~mL})$ under nitrogen. After 15 minutes $\mathrm{Et}_{2} \mathrm{O}: \mathrm{BF}_{3}(20 \mu \mathrm{L})$ was added and the reaction mixture protected from light and stirred for the next 40 minutes. The mixture was evaporated under reduced pressure and then subjected to chromatography $\left(\mathrm{Al}_{2} \mathrm{O}_{3}\right.$, II grade, $\mathrm{CH}_{2} \mathrm{Cl}_{2}$ ). The porphyrinogen was eluted as a deep blue fraction. After chromatography, the product was precipitated from $\mathrm{CH}_{2} \mathrm{Cl}_{2}$ with $\mathrm{CH}_{3} \mathrm{OH}$ as blue powder/crystals. Yield (for the mixture of stereoisomers) $79.04 \mathrm{mg}(95 \%)$.

Data for 1: ${ }^{1} \mathrm{H}$ NMR (chloroform- $d, 298 \mathrm{~K}$ ): 8.09 (d, $\left.4 \mathrm{H}, 2^{1}, 3^{1}, 12^{1}, 13^{1}, 3^{3} \mathrm{~J}=9.6 \mathrm{~Hz}\right) ; 7.72(\mathrm{~s}, 2 \mathrm{H}, 21,23-\mathrm{H})$; $7.41\left(\mathrm{t}, 2 \mathrm{H}, 2^{3}, 12^{3}-\mathrm{H},{ }^{3} \mathrm{~J}=10.1 \mathrm{~Hz}\right) ; 7.04(\mathrm{~s}, 16 \mathrm{H}, m$-Tol, $o$-Tol), 6.92 (t, 4H, $\left.2^{2}, 3^{2}, 12^{2}, 13^{2},{ }^{3} J=9.7 \mathrm{~Hz}\right) ; 6.49$ (s, $4 \mathrm{H}, 7,8-\mathrm{H}, 12,13-\mathrm{H}) ; 6.18$ (s, 4H, 5,10,15,20-H); 2.27 (s, $12 \mathrm{H}, p$-Tol- $\left.\mathrm{CH}_{3}\right)$. UV-Vis $\left(\mathrm{CH}_{2} \mathrm{Cl}_{2}, \lambda_{\max }[\mathrm{nm}](\log \varepsilon)\right)$ : 616 (3.38), 673 (3.27), 747 (2.80). HRMS (ESI, $\mathrm{m} / \mathrm{z}$ ): 832.3189 (832.3192 for $\mathrm{C}_{60} \mathrm{H}_{48} \mathrm{~S}_{2}$ ); elemental analysis 
calcd (\%) for $\mathrm{C}_{60.5} \mathrm{H}_{50} \mathrm{~S}_{2}\left(\mathbf{1} \cdot 0.5 \mathrm{CH}_{3} \mathrm{OH}\right): \mathrm{C} 85.58$, H 5.89, S 7.54, found: C 85.35, H 6.34, S 7.95.

$\mathbf{5 , 1 0 , 1 5 , 2 0 - t e t r a - p - t o l y l - 2 2 , 2 4 - d i t h i a d i a z u l i p o r p h y r i n ~}$ (2): $1(0.024 \mathrm{mmol}, 20.0 \mathrm{mg})$ and DDQ $(0.096 \mathrm{mmol}$, $21.8 \mathrm{mg}$ ) were dissolved in $50 \mathrm{~mL}$ freshly distilled $\mathrm{CH}_{2} \mathrm{Cl}_{2}$. The solution was subsequently evaporated under reduced pressure. The product of the reaction was then dissolved in $40 \mathrm{~mL}$ of freshly distilled THF and $\mathrm{SnCl}_{2}$ $(75 \mathrm{mg}$ ) was added. The color of the solution has changed from navy blue to dark red. The volume of the solution was reduced to $6-8 \mathrm{~mL}$ and the mixture was subjected to chromatography $\left(\mathrm{Al}_{2} \mathrm{O}_{3}\right.$, II grade, $\mathrm{CH}_{2} \mathrm{Cl}_{2}$ or $\mathrm{Al}_{2} \mathrm{O}_{3}$, III grade, toluene). The product was eluted as the first fraction, which gave a shiny violet powder after evaporation. The reaction is quantitative although some amount of the 5,10,15,20-tetratolyl-22,24-dithiadiazuliporphyrin dication is regenerated during chromatography. Yield after chromatography $17.9 \mathrm{mg}(90 \%)$.

Data for 2: ${ }^{1} \mathrm{H}$ NMR (toluene- $d_{8}, 298 \mathrm{~K}$ ): 10.29 (s, 4H, 7,8-H, 12,13-H); 7.62 (d, 4H, $2^{1}, 3^{1}, 12^{1}, 13^{1},{ }^{3} \mathrm{~J}=10.1$ $\mathrm{Hz}) ; 7.33\left(8 \mathrm{H}, 5,10,15,20-o-\mathrm{Tol},{ }^{3} J=8.0 \mathrm{~Hz}\right) ; 7.02(\mathrm{~s}$, $2 \mathrm{H}, 21,23-\mathrm{H}) ; 6.95$ (d, 8H, 5,10,15,20-m-Tol, ${ }^{3} J=7.8$ $\mathrm{Hz}) ; 6.72\left(\mathrm{t}, 4 \mathrm{H}, 2^{2}, 3^{2}, 12^{2}, 13^{2}, 3 \mathrm{~J}=9.8 \mathrm{~Hz}\right) ; 6.25(\mathrm{t}, 2 \mathrm{H}$, $2^{3}, 12^{3}-\mathrm{H},{ }^{3} \mathrm{~J}=9.8 \mathrm{~Hz}$ ); 2.33 ( $\mathrm{s}, 12 \mathrm{H}, p$-Tol-CH $\mathrm{CH}_{3}$. UV-Vis $\left(\mathrm{CH}_{2} \mathrm{Cl}_{2}, \lambda_{\max }[\mathrm{nm}](\log \varepsilon)\right): 442$ (4.84); 514 (4.66), 533 (4.34); HRMS (for mixture of differently oxidized forms), (ESI, m/z): $828.2890\left(828.2879\right.$ for $\left.\mathrm{C}_{60} \mathrm{H}_{44} \mathrm{~S}_{2}\right)$; elemental analysis calcd (\%) for $\mathrm{C}_{64} \mathrm{H}_{52} \mathrm{~S}_{2} \mathrm{O}(\mathbf{2} \cdot \mathrm{THF})$ : $\mathrm{C}$ 85.29, H 5.82, S 7.12, found: C 85.44, H 6.42, S 7.91. $\mathbf{5 , 1 0 , 1 5 , 2 0 - t e t r a - p - t o l y l - 2 2 , 2 4 - d i t h i a d i a z u l i p o r p h y r i n ~}$ dication, $\mathbf{2}^{2+}$ : Bromine $(20 \mu \mathrm{L})$ was added to solution of $2,(0.036 \mathrm{mmol}, 30.0 \mathrm{mg})$ in $50 \mathrm{~mL}$ of freshly distilled $\mathrm{CH}_{2} \mathrm{Cl}_{2}$. The color of the solution changed quickly from dark red to navy blue. The solid $2^{2+} \cdot 2\left[\mathrm{Br}_{3}\right]^{-}$was precipitated by addition of $n$-pentane to the reaction mixture. ${ }^{1}$ The reaction is quantitative.

Data for $\mathbf{2}^{2+} \cdot 2\left[\mathrm{Br}_{3}\right]^{-}$: ${ }^{1} \mathrm{H}$ NMR (acetonitrile- $d_{3}, 298 \mathrm{~K}$ ): 8.98 (s, 4H, 7,8-H, 12,13-H); 8.22 (br. $8 \mathrm{H}, 5,10,15,20-o-$ Tol); $8.20\left(\mathrm{~d}, 4 \mathrm{H}, 2^{1}, 3^{1}, 12^{1}, 13^{1},{ }^{3} \mathrm{~J}=10.1 \mathrm{~Hz}\right) ; 8.16(\mathrm{t}$, $\left.2 \mathrm{H}, 2^{3}, 12^{3}-\mathrm{H},{ }^{3} \mathrm{~J}=9.6 \mathrm{~Hz}\right) ; 8.03\left(\mathrm{t}, 4 \mathrm{H}, 2^{2}, 3^{2}, 12^{2}, 13^{2},{ }^{3} \mathrm{~J}\right.$ $=9.8 \mathrm{~Hz}) ; 7.83\left(\mathrm{~d}, 8 \mathrm{H}, 5,10,15,20-m-\mathrm{Tol},{ }^{3} J=7.6 \mathrm{~Hz}\right)$; $2.74\left(\mathrm{~s}, 12 \mathrm{H}, p\right.$-Tol- $\left.\mathrm{CH}_{3}\right)$. UV-Vis $\left(\mathrm{CH}_{2} \mathrm{Cl}_{2}, \lambda_{\max }[\mathrm{nm}]\right.$ $(\log \varepsilon)$ ): 325 (4.3); 4424 (4.82); 4964 (4.75); 580 (5.02);

MS (ESI, m/z): $413.7,828.3$ (for $\mathbf{2}^{2+}$ and $\mathbf{2}^{++}$mixture); elemental analysis calcd (\%) for $\mathrm{C}_{66} \mathrm{H}_{58} \mathrm{~S}_{2} \mathrm{Br}_{6} \mathrm{Cl}_{2}$ $\left(2^{2+} \cdot 2\left[\mathrm{Br}_{3}\right]^{-} \cdot \mathrm{C}_{5} \mathrm{H}_{12} \cdot \mathrm{CH}_{2} \mathrm{Cl}_{2}\right)$ :, C 54.61, H 4.00, S 4.41, found: C 54.38, H 4.01, S 5.50.

ESR spectra were recorded on the Bruker ESP300 spectrometer operating with X-band equipped with a ER $035 \mathrm{M}$ gaussmeter and a HP 53550B microwave frequency counter. Radical $\mathbf{2}^{\mathbf{*}}$ for the ESR measurement was obtained by addition of $\mathrm{SnCl}_{2}$ in THF to the solution of $2^{2+}$ in $\mathrm{CH}_{2} \mathrm{Cl}_{2}$. Progress of the reaction was monitored by UV-vis spectroscopy. Conditions: microwave frequency $v=9.75602 \mathrm{GHz}$, microwave power 3.17 $\mathrm{mW}$, modulation amplitude, $2.744 \mathrm{~T}$; modulation frequency $100 \mathrm{kHz}$.

UV-vis spectra were recorded on the Hewlett-Packard 8435 diode-array spectrophotometer.

Mass spectra were obtained on the AMD-604 spectrometer using the ESI method.

Electrochemical measurements were performed on the EA9C Multifunctional Electrochemical Analyzer using platinum or glassy-carbon disk as a working electrode and platinum wire as the auxiliary electrode. The saturated calomel or silver chloride electrodes were used as the reference electrodes and they were separated from the bulk solution by a glassy diaphragm connected to a bridge filled with the electrolyte solution.

X-ray Crystallography. Diffraction data were collected on a Kuma KM4CCD diffractometer using MoKa radiation $(0.71073 \AA)$. The presented crystal structures were solved by direct methods using the SHELXS $97^{2}$ program and subsequently refined with SHELXL97. ${ }^{3}$ Crystal data were contained in Table 1 . In the structure of $\mathbf{2}$ solvent molecules and one of the sulfur atom demonstrated slight positional disorder.

NMR Spectroscopy. NMR spectra were recorded on a $500 \mathrm{MHz}$ Bruker Avance spectrometer $\left({ }^{1} \mathrm{H} 500.13 \mathrm{MHz}\right.$, ${ }^{13} \mathrm{C} 125.77 \mathrm{MHz}$,) equipped with a broadband inverse gradient probehead.

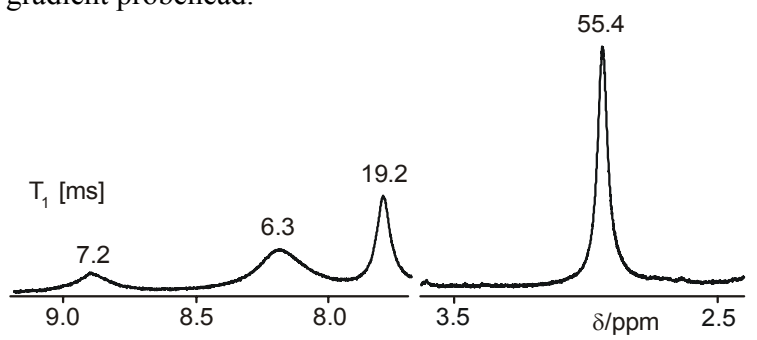

Figure. Longitudinal relaxation times for $\mathbf{2}^{2+}$ with a small amount of $\mathbf{2}^{++}$(chloroform- $d, 298 \mathrm{~K}$ ) obtained using the inversion recovery method.

(1) The $\mathrm{Br}_{3}^{-}$is preferentially formed in 2 dichloromethane solution what accounts for its presences as a counteranion of $\mathbf{2}^{2+}$ in the solid state. For formation of $\mathrm{Br}_{3}^{-}$see: Bellucci, G.; Roberto Bianchini, R.; Ambrosetti, R.; Ingrossog. G. J. Org. Chem. 1986, 50, 3313-3318

(2) Sheldrick, G. M. SHELXS97 - Program for Crystal Structure Solution, 1997, University of Göttingen.

(3) Sheldrick, G. M. SHELXL97 - Program for Crystal Structure Refinement, 1997, University of Göttingen. 